DARIUSZ MISIEJUK

[Wrocław]

\title{
NIEZNANE WSPOMNIENIA \\ ZAPOMNIANEGO DZIAŁACZA LUDOWEGO
}

\author{
Wrocławski Rocznik \\ Historii Mówionej \\ Rocznik I, 2011 \\ ISSN 2084-0578
}

W zasobie Instytutu Pamięci Narodowej przechowywane są przede wszystkim akta wytworzone przez funkcjonariuszy aparatu bezpieczeństwa PRL. Jednakże w trakcie realizacji niektórych działań operacyjnych funkcjonariusze ci rekwirowali różnego rodzaju dokumentację osób, które znalazły się w kręgu ich zainteresowania. Tym sposobem do archiwów organów bezpieczeństwa państwa (stąd zaś później do IPN) dostały się kolekcje przeróżnych zdjęć rodzinnych, korespondencje, rozmaite pamiętniki i wspomnienia, broszury, ulotki, wiele z nich obecnie unikatowych.

Pod koniec lat 60. ubiegłego wieku funkcjonariusze Służby Bezpieczeństwa weszli w posiadanie wspomnień oraz różnego rodzaju osobistych dokumentów powracającego z emigracji Władysława Zaremby. Przejęte wówczas listy, artykuły pisane przez niego do emigracyjnych czasopism, notatki i wspomnienia składają się obecnie na swoistą spuściznę po tym wciąż mało znanym działaczu ludowym. Obecnie - dzięki szerokiemu dostępowi do akt komunistycznego aparatu represji - zarówno wspomnienia, jak i inne dokumenty dotyczące życia i działalności Władysława Zaremby stały się terenem eksploracji badawczych.

Celem niniejszego szkicu jest przybliżenie informacji o osobie Władysława Zaremby, jednego z czołowych działaczy Polskiego Stronnictwa 
Ludowego w kraju i na emigracji, postaci niemal całkowicie dziś zapomnianej ${ }^{1}$. Przede wszystkim jednak informacji o wspomnieniach, które spisał na emigracji, a które nie były szerzej znane wśród historyków².

\section{Władysław Zaremba}

Urodził się w biednej rodzinie chłopskiej w Orzechówce w powiecie brzozowskim 30 lipca 1902 r. Od wczesnej młodości wychowywany był w duchu patriotyzmu oraz poszanowania idei rodzącego się wówczas ruchu ludowego. Jego pradziadek brał udział w powstaniu styczniowym, który później z obawy przed carskimi prześladowaniami osiedlił się w Galicji. Dziadek zaś - jeden z pierwszych ludowców w okolicy - czytywał mu czasopisma ludowe, m.in. „Wieniec - Pszczółkę”, wychowując w poszanowaniu tradycji chłopskich.

Trudna sytuacja materialna rodziny zmusiła młodego Władysława do zakończenia edukacji na dwóch klasach szkoły powszechnej. Po śmierci ojca, od dwunastego roku życia, musiał pracować na utrzymanie matki i czterech młodszych sióstr. Wszelkie braki w wykształceniu nadrabiał jednak otwartością i ogólną ciekawością świata ${ }^{3}$.

1 Literatura przedmiotu dotycząca Władysława Zaremby jest nader uboga. Podsumowania dotychczasowego stanu badań nad osobą Władysława Zaremby dokonał w trakcie ogólnopolskiej konferencji archiwalnej w Supraślu w czerwcu 2011 r. D. Misiejuk, wygłaszając referat nt.: Władysław Zaremba (nie)znany działacz ludowy w kraju i na emigracji. Teksty wygłoszonych wówczas referatów zostaną opublikowane na przełomie 2011 i $2012 \mathrm{r}$.

2 W trakcie IV Kongresu Historyków Wsi i Ruchu Ludowego Franciszek Gryciuk wygłosił referat poświęcony życiu i działalności Władysława Zaremby, który powstał na podstawie wspomnień tegoż działacza ludowego. Tekst został opublikowany w materiałach pokonferencyjnych, zob. F. Gryciuk, Wtadysław Zaremba, [w:] Represje wobec wsi i ruchu ludowego (1944-1989), t. 4: Między apologia a negacja, red. J. Gmitruk, E. Leniart, Warszawa 2010, s. 197-216. Obszerne fragmenty wspomnień Zaremby zostały opublikowane w książce: K. Maler, D. Misiejuk, 65 lat Polskiego Stronnictwa Ludowego na Ziemi Głubczyckiej, Głubczyce 2011. Wybrane do publikacji fragmenty wspomnień dotyczą lat 1945-1949.

3 W dokumentach Służby Bezpieczeństwa znajduje się informacja, iż Władysław Zaremba ukończył w Londynie szkołę polityczną. W trakcie dotychczasowych badań nie udało się zweryfikować tej informacji. 
Kampanię polsko-bolszewicką przemierzył w szeregach 38. Pułku Piechoty Strzelców Lwowskich. Po ustaniu działań wojennych wraz z całą rodziną przeniósł się do powiatu Podhajce w województwie tarnopolskim, gdzie zakupił niewielkie gospodarstwo. Organizując je, stosował większość nowinek w rolnictwie. Efekty przeprowadzonej przez niego modernizacji zachęciły do zmian w gospodarce innych chłopów. Obok pracy na roli aktywnie działał w ruchu ludowym, pozostając pod wpływem Wincentego Witosa, z którym wielokrotnie się spotykał, m.in. jako prezes Zarządu Powiatowego SL w Podhajcach. W 1922 r. został wybrany członkiem rady gminy Halicz, a od 1934 r. pełnił funkcję wójta tej gminy. Propagował czytelnictwo prasy ludowej, uświadamiał politycznie chłopów, wskazywał na konieczność stosowania nowych technik uprawy i nowych narzędzi celem podniesienia efektywności roli. Jako nowoczesny chłop był człowiekiem praktycznym i realistą, wierzył w możliwość gospodarczego przeobrażenia wsi polskiej.

Po zamachu majowym był prześladowany przez władze sanacyjne jako działacz ludowy i zdecydowany krytyk rządów Józefa Piłsudskiego. Wielokrotnie go zatrzymywano i osadzano w areszcie, m.in. w owianym złą sławą więzieniu u Brygidek we Lwowie. Jednakże kary i represje administracyjne nie zniechęciły go do kontynuowania działalności społeczno-politycznej. Od 1931 r. był wiceprezesem Zarządu Wojewódzkiego SL we Lwowie oraz od 1937 r. członkiem Rady Naczelnej SL.

Osobiście kierował przygotowaniami do strajku chłopskiego w 1937 r. w powiecie podhajeckim. Zatrzymany 25 sierpnia 1937 r. przebywał w areszcie do rozprawy sądowej, która odbyła się 18 stycznia 1938 r. Za udział w strajku chłopskim sąd skazał go na 9 miesięcy więzienia ${ }^{4}$.

Brał udział w kampanii wrześniowej 1939 r. Ciężko ranny w brzuch podczas bombardowania wrócił do domu w październiku 1939 r., gdy powiat podhajecki znajdował się już pod okupacją sowiecką. 10 lutego 1940 r. sowieci deportowali w głąb ZSRR część ludności polskiej z terenów nadgranicznych. Władysław Zaremba wraz z rodziną zostali wywiezieni do przysiółka Zimowoja Teja nad rzeką Jenisej, a następnie

4 Strajk chtopski w 1937 r. Dokumenty archiwalne, t. 2, Warszawa 1960, s. 341, przyp. 9 (dokument nr 112 - Strajk Chłopski w Małopolsce). Zob. także: B. Magusiak, Przeszłość, teraźniejszość, przyszłość Polskiego Stronnictwa Ludowego, [w:] Pamiętniki Nowego Pokolenia Chtopów Polskich. Materiały konkursowe. Tom sygnalny, wybór i oprac. A. Budzyński, J. Gmitruk, Warszawa 1996, s. 211. 
do Taszkientu. W 1942 r. Władysław nawiązał kontakt z ambasadorem RP w Moskwie, Stanisławem Kotem. Dzięki niemu rodzina Zarembów wydostała się z ZSRR. W marcu 1942 r. Władysław Zaremba dotarł do Londynu. Tam odnowił kontakty z innymi działaczami ludowymi, m.in. ze Stanisławem Mikołajczykiem. Jego poparcie przyczyniło się do tego, że Zaremba został początkowo członkiem, a w grudniu 1943 r. wiceprzewodniczącym Rady Narodowej RP na uchodźstwie ${ }^{5}$.

Współpraca Zaremby z Mikołajczykiem trwała także po ich powrocie do kraju w połowie 1945 r. Zaremba osiadł na Śląsku, gdzie w powiecie głubczyckim przejął duże poniemieckie gospodarstwo. Jednocześnie z ramienia PSL otrzymał powołanie na posła do Krajowej Rady Narodowej ${ }^{6}$, wszedł w skład Rady Naczelnej, a następnie do Naczelnego Komitetu Wykonawczego Polskiego Stronnictwa Ludowego. Współorganizował struktury tej partii na Śląsku i Opolszczyźnie, m.in. został wiceprezesem Zarządu Wojewódzkiego PSL w Katowicach7. Dzięki jego osobistemu zaangażowaniu powstały pierwsze koła PSL na terenie powiatu głubczyckiego, a także zorganizowano Związek Młodzieży Wiejskiej RP „Wici”. Szykany administracyjne sprawiły, iż dopiero pod koniec maja 1946 r. powołano Zarząd Powiatowy PSL w Głubczycach. Władze powiatowe obawiały się siły PSL, ponieważ szeregi tej partii liczyły w połowie roku ok. 2,5 tys. członków, więcej niż PPR, PPS i SL razem wzięte ${ }^{8}$.

5 R. Turkowski, Rada Narodowa Rzeczypospolitej Polskiej (1939-1945), [w:] Władze RP na obczyźnie podczas II wojny światowej 1939-1945, red. Z. Błażyński, Londyn 1994, s. 452. Więcej zob. E. Duraczyński, R. Turkowski, O Polsce na uchodźstwie. Rada Narodowa Rzeczypospolitej Polskiej 1939-1945, Warszawa 1997, tam wiele wzmianek na temat Władysława Zaremby.

6 Opozycja parlamentarna w Krajowej Radzie Narodowej i Sejmie Ustawodawczym 1945-1947, wybór, wstęp i oprac. R. Turkowski, Warszawa 1997, s. 337.

7 K. Mieroszewski, Polskie Stronnictwo Ludowe, [w:] Województwo ślaskie 1945-1950. Zarys dziejów politycznych, red. A. Dziurok, R. Kaczmarek, Katowice 2007, s. 313314.

8 D. Misiejuk, Działania organów bezpieczeństwa państwa wobec PSL w powiecie glubczyckim w okresie wyborów do Sejmu Ustawodawczego 1947 r., [w:] PSL w realiach społeczno-politycznych Dolnego Ślaska drugiej połowy lat czterdziestych XX w., wstęp i oprac. J. Syrnyk, Wrocław 2008, s. 57. Zob. też B. Bidzińska-Jakubowska, Polskie Stronnictwo Ludowe na Ślasku Opolskim i jego miejsce w antykomunistycznej opozycji w latach 1945-1947, Opole 1993; R. Turkowski, Polskie Stronnictwo Ludowe w obronie demokracji: 1945-1949, Warszawa 1992. 
W wyniku manipulacji i fałszerstw w wyborach do Sejmu Ustawodawczego w 1947 r. Władysław Zaremba nie otrzymał mandatu poselskiego. Został aresztowany przez funkcjonariuszy Urzędu Bezpieczeństwa, w związku z podejrzeniem udziału w ucieczce Stanisława Mikołajczyka w listopadzie 1947 r. Przetrzymywany był w więzieniach UB w Głubczycach, Katowicach, a następnie w Warszawie ${ }^{9}$. Wykorzystując fakt pobytu w więzieniu, w kwietniu 1948 r. tzw. władza ludowa odebrała mu gospodarstwo rolne i młyn, którym zarządzał ${ }^{10}$. Z więzienia został wypuszczony na początku czerwca 1948 r. Nie oznaczało to jednak końca prześladowań oraz szykan administracyjnych. Po powrocie na Śląsk w krótkim czasie otrzymał decyzję nakazującą mu osiedlenie się poza terenem powiatu. Pozostawał też pod ustawicznym nadzorem funkcjonariuszy aparatu bezpieczeństwa.

W tej sytuacji podjął decyzję o opuszczeniu kraju. 22 grudnia 1948 r. Zaremba przedostał się do Berlina, skąd później dotarł do USA. Tam wspólnie ze Stanisławem Mikołajczykiem zakupił 400-akrową farmę. Mimo ciężkiej pracy na farmie niemal od razu włączył się w nurt życia politycznego. Wszedł w skład Naczelnego Komitetu Wykonawczego PSL, został wiceprezesem Związku Przyjaciół Wsi Polskiej w Stanach Zjednoczonych, pisywał do prasy emigracyjnej, występował w audycjach Radia Wolna Europa oraz Głosu Ameryki ${ }^{11}$.

W 1954 r. doszło do kryzysu i rozłamu w Polskim Stronnictwie Ludowym na emigracji. Oponenci Stanisława Mikołajczyka, wśród których był również Władysław Zaremba, zarzucali prezesowi PSL zbytnią koncentrację władzy oraz nierozliczanie się z otrzymywanych dotacji na działalność ludowców. Nie uznając jego dalszego przywództwa,

9 D. Misiejuk, Działania komunistycznego aparatu bezpieczeństwa wobec Władysława Zaremby, [w:] K. Maler, D. Misiejuk, 65 lat Polskiego Stronnictwa Ludowego..., s. $31-33$.

10 Ibidem, s. 87, przyp. 90.

11 W Rozgłośni Polskiej Radia Wolna Europa Zaremba wystąpił m.in. 2 VI 1954 r. z okazji Zielonych Świąt, apelując do słuchaczy: „Wy, chłopi, macie zdrowy rozum i chłopski rozsądek, który nigdy nie zawiedzie, nie słuchajcie tych, co was okłamują dzisiaj [...] nie wolno wam rezygnować z ojcowizny, oddawać dobrowolnie na kołchozy”. Kolejne przemówienie wygłosił 3 XII 1954 r. w związku z wyborami, zob. Stanisław Mikołajczyk $w$ dokumentach aparatu bezpieczeństwa. T. 2: Działalność w latach 1947-1958, Warszawa-Łódź 2010, nr 126, s. 354-355; nr 140, s. 434-435; nr 176 , s. $546-547$. 
utworzyli oni tzw. PSL-NKW. Formalnie używali w dalszym ciągu nazwy Polskie Stronnictwo Ludowe, uważając, iż są reprezentantami ruchu ludowego na emigracji. Mikołajczyk i jego zwolennicy uważali natomiast, iż to oni są przedstawicielami prawowitych władz PSL. Na Kongresie PSL w Paryżu w 1955 r., Mikołajczyk doprowadził do usunięcia swoich oponentów z szeregów partii ${ }^{12}$.

W PSL-NKW Władysław Zaremba początkowo pełnił funkcję członka Naczelnego Komitetu Wykonawczego, został także redaktorem miesięcznika „Głos Ludu”. Po kolejnym konflikcie wewnętrznym w PSL jesienią 1960 r., kiedy to Mikołajczyk usunął z szeregów partii Adama Bitońskiego $^{13}$ i jego współpracowników, doszło w 1961 r. w Brukseli do tzw. zjazdu zjednoczeniowego PSL, którego przedstawiciele nie uznawali przywództwa Stanisława Mikołajczyka. Wśród wyłonionych wówczas władz partii znalazł się Władysław Zaremba jako prezes NKW-PSL. Zaremba został także redaktorem i wydawcą organu prasowego partii, tj. „Biuletynu Informacyjnego NKW-PSL”. Siła oddziaływania tego odłamu PSL na emigrację pozostała jednak niewielka ${ }^{14}$.

Przemiany polityczne w kraju w roku 1956 oraz dojście do władzy Władysława Gomułki stanowiły punkt zwrotny w podejściu Zaremby do władz PRL ${ }^{15}$. Od tego też czasu w korespondencji z członkami rodziny wyrażał chęć powrotu do kraju. Ostatecznie w 1967 r. podjął starania o uzyskanie w Ambasadzie PRL w Waszyngtonie paszportu kon-

12 R. Turkowski, Polski ruch ludowy na obczyźnie 1945-1989, [w:] Represje wobec wsi i ruchu ludowego, t. 4..., s. 50-51; R. Turkowski, Polski ruch ludowy na emigracji (1944-1991). Dokumenty $i$ materiaty, cz. 1-3, Kielce 2005-2007, gdzie jest wiele wzmianek o Władysławie Zarembie. Na temat działalności W. Zaremby na emigracji zob. również A. Friszke, Życie polityczne emigracji, Warszawa 1999.

13 O współpracy Adama Bitońskiego z wywiadem cywilnym PRL zob. Stanisław Mikotajczyk w dokumentach aparatu bezpieczeństwa, t. 2..., s. 240-241, przyp. 2.

14 R. Turkowski, Polski ruch ludowy na obczyźnie 1945-1989, [w:] Represje wobec wsi i ruchu ludowego, t. 4..., s. 50-51.

15 P. Ziętara, Emigracja wobec Października. Postawy polskich środowisk emigracyjnych wobec liberalizacji w PRL w latach 1955-1957, Warszawa 2001, s. 237-238; B. Dereń, Aparat bezpieczeństwa wobec niezależnych ludowców krakowskich $w$ latach 1957-1970, [w:] Represje wobec wsi i ruchu ludowego (1956-1989), t. 2: Materiaty z konferencji naukowej 27-28 listopada 2003 r. w Rzeszowie pt. „Wieś i ruch ludowy a wtadza w PRL w latach 1956-1989”, red. J. Gmitruk, Z. Nawrocki, Warszawa 2004, s. 142 . 

przypłynął do Gdyni. Po powrocie z emigracji nie podjął jednak żadnej działalności politycznej. Zmarł 25 sierpnia 1972 r.

\section{SB a wspomnienia Zaremby}

W trakcie kontroli granicznej funkcjonariusze Urzędu Celnego w Gdyni poddali szczegółowej rewizji bagaż Władysława Zaremby. Szczególną uwagę funkcjonariuszy zwróciły teczki papierowe, które zawierały m.in. maszynopis jego wspomnień, liczący 314 stron ${ }^{16}$, różnego rodzaju wypisy i wycinki prasowe oraz listy ${ }^{17}$. Analiza zawartości i treści tych materiałów skłoniła celników do zarekwirowania całości na podstawie art. 10 ówczesnego prawa celnego. Następnie wszystkie materiały zostały przekazane do Wojewódzkiego Urzędu Kontroli Prasy Publikacji i Widowisk w Gdańsku celem uzyskania orzeczenia w przedmiocie zatrzymania bądź zwrotu całości Zarembie. WUKPPiW stwierdził, iż „materiały te są rękopisami i notatkami stanowiącymi prywatną własność właściciela, stanowią one wyraz jego zainteresowań naukowych [...] wobec czego można je zwolnić i zwrócić właścicielowi”. Powyższa decyzja została jednak podważona przez funkcjonariuszy z Wydziału II Służby Bezpieczeństwa KW MO (kontrwywiad) w Gdańsku. Wszystkie zajęte materiały przesłano później do Ministerstwa Spraw Wewnętrznych celem podjęcia ostatecznej decyzji w porozumieniu z Głównym Urzędem Kontroli Prasy Publikacji i Widowisk ${ }^{18}$. Decyzją wicedyrektora Departamentu III MSW z dnia 11 lutego 1969 r. materiały skonfisko-

16 Według siostrzeńca Zaremby, Bolesława Magusiaka, wuj przywiózł ze sobą z USA dwa tomy wspomnień. Jeden został zarekwirowany na granicy przez celników i SB, natomiast drugi udało się - dzięki nieuwadze funkcjonariuszy - zabezpieczyć przed konfiskatą, zob. Relacja B. Magusiaka w zbiorach Powiatowego Muzeum Ziemi Głubczyckiej w Głubczycach. „Uratowany” tom wspomnień miał być później przekazany jednemu z redaktorów czasopisma „Więzi”. W trakcie dotychczasowych badań nie udało się zweryfikować tych informacji.

17 Wykaz zakwestionowanych materiałów znajduje się w piśmie Departamentu II MSW: Archiwum Instytutu Pamięci Narodowej, Biuro Udostępniania (dalej: AIPN BU), sygn. 0204/21, t. 1, Spis zawartości materiałów Władysława Zaremby przekazanych do Departamentu III MSW, Warszawa dn. 23 X 1968 r., k. 25-26.

18 Ibidem, Pismo KWMO w Gdańsku do Wydz. IX Dep. II MSW, Gdańsk dn. 19 IX 1968 r., k. 22. 
wane przez Urząd Celny i przesłane do MSW zostały w ministerstwie zatrzymane $^{19}$. Mimo wielokrotnych monitów o zwrot zajętych materiałów Zaremba nigdy ich nie otrzymał. Obecnie spuścizna Władysława Zaremby dostępna jest dla badaczy w postaci oryginału ${ }^{20}$ oraz mikrofilmu ${ }^{21}$ sporządzonego przez funkcjonariuszy SB.

Bogactwo postaci, faktów, unikatowych relacji o życiu wsi polskiej predestynuje te wspomnienia do zaprezentowania szerokiemu gronu czytelników w postaci samodzielnej publikacji. Dotychczas zostały opublikowane jedynie wybrane fragmenty wspomnień Władysława Zaremby, w których opisuje swą działalność w kraju od powrotu w 1945 r. do ucieczki za granicę w grudniu 1948 r. ${ }^{22}$

\section{Okoliczności i czas powstania}

Moje wspomnienia Władysław Zaremba pisał, kiedy z wolna gasł jego zapał polityczny, a on przestał być czynnym działaczem ruchu ludowego. Czas pisania utrwalił tu i ówdzie gorzkie ślady w postaci oceny działaczy ludowych na emigracji, a przede wszystkim Stanisława Mikołajczyka. Ten zaś - ciesząc się poparciem rządu amerykańskiego - ostro zwalczał wszystkich secesjonistów, inne odłamy emigracyjnego PSL. $Z$ jego inspiracji odebrano Zarembie stypendium Komitetu Wolnej Europy, utracił także inne dochody i zmuszony był podjąć w połowie lat 50. $\mathrm{XX}$ w. posadę dozorcy ${ }^{23}$. W omawianych wspomnieniach brak jednak informacji o śmierci Mikołajczyka, która nastąpiła w grudniu 1966 r. Zaremba, wówczas zagorzały przeciwnik Mikołajczyka, niewątpliwie odnotowałby ów fakt w tekście. Wobec powyższego śmierć prezesa PSL może stanowić terminus ante quem powstania omawianego dzieła.

19 Ibidem, k. 33.

20 Wspomnienia i inne materiały zarekwirowane Zarembie zostały zarchiwizowane wraz z całością dokumentacji urzędowej w tej sprawie: IPN BU, sygn. 0204/21, t. $1-4$.

21 AIPN BU, sygn. 01224/854.

22 W. Zaremba, Moje wspomnienia [fragmenty], redakcja naukowa, wstęp i oprac. D. Misiejuk, [w:] K. Maler, D. Misiejuk, 65 lat Polskiego Stronnictwa Ludowego..., s. 40-89.

23 AIPN BU, MSW, sygn. 01168/174 [Notatka informatora Departamentu I MSW ps. „Korespondent” - Jan Parafiniak, z dn. 14 kwietnia 1958 r.], k. 29 (cyfrowa kopia zmikrofilmowanych akt). 
Czy można jednak ustalić przypuszczalny termin rozpoczęcia przez Zarembę prac nad tekstem wspomnień? Rozpoczął je od słów: „Jestem synem wsi polskiej, starym już człowiekiem, niezdolnym już do pracy fizycznej. Jestem już na pensji starczej, na którą to potrącano mi każdego tygodnia [z] mego zarobku. Nie jestem dla nikogo ciężarem mej starości. Uciułałem sobie z ciężkiej mej pracy nieco oszczędności, bo pensja nie wystarczyła by na moje skromne nawet życie, z której trzeba żyć. Po przejściu na emeryturę życie moje stawało się coraz nudniejsze. Postanowiłem napisać o moich spostrzeżyniach od najmłodszych lat mego zapamiętania. Tem postanowiłem wypełnić sobie czas i nudnego życia, osamotnionego" 24 .

Istotne znaczenie w ustaleniu czasu powstania omawianego tekstu mają dwa listy Zaremby do nieznanych adresatów w kraju, znajomych działaczy ruchu ludowego. Z korespondencji tej wynika, że przeszedł on na emeryturę w 1964 r., bowiem w liście z lipca 1966 r. zapisał: „Ja już dwa lata poszedłem na rentę starczą, a to dlatego, że mi mój stan zdrowia nie pozwalał więcej pracować” ${ }^{25}$. Wiadomo również, że rok czasu przebywał na kuracji we Włoszech, z której wrócił do Nowego Jorku w drugiej połowie 1965 r. W liście z 12 lutego 1966 r. do innego działacza ludowego w kraju zapisał: „Parę miesięcy temu pisma Poloni zaczyny wiele pisać o Piłsudskim, dla omszania zupy, czyli pism. Więc usiadłem do maszynki i z oburzeniem wielkim napisałem w oparciu o dokumenty hostorji, uderzyłem mocno w Piłsudskiego". Wspomniane artykuły poświęcone osobie marszałka powstały zapewne w 1965 r. z okazji przypadającej wówczas 30. rocznicy śmierci Piłsudskiego. W innym miejscu tego samego listu zanotował: „Pisząc pamiętniki o naszych czasach i walk z sanacją, nie ominąłem Was Kolegi i Przyjacielu" ${ }^{26}$. Natomiast we wspomnieniach, pisząc o siostrach pozostałych w kraju, dodał: „Jest obecnie 1966 rok, żyją mi wszystkie i dobrze się im powodzi”"27. W związku z powyższym, z dużą dozą prawdopodobieństwa można przyjąć, iż prace nad tekstem wspomnień rozpoczął Zaremba na przełomie 1965 i 1966 r., zapewne po powrocie z Włoch.

\footnotetext{
24 AIPN BU, sygn. 0204/21, t. 2 [Władysław Zaremba, Moje wspomnienia], k. 1.

25 Ibidem, t. 4 [List do nieznanego adresata], New York 16 lipca 1966, k. 49.

26 Ibidem, t. 1 [List do nieznanego adresata], New York 12 lutego 1966, k. 4.

27 Ibidem, t. 2 [Władysław Zaremba, Moje wspomnienia], k. 29.
} 
Praca nad wspomnieniami nie była ciągła, o czym może świadczyć numeracja kart - przykładowo istnieją dwie karty o numerze 303, jedna zapisana w całości, druga zapisana jedynie jednym zdaniem; poprawki nanoszone na tekście, uzupełnienia i powtórzenia treści, np. relacja z pobytu w aresztach UB w Katowicach i Warszawie. Na kartach 298-314 znajduje się opis sytuacji Polaków na Wschodzie pod okupacją sowiecką, wysiedlenia ze wsi Mazury i deportacji na Syberię do przysiółka Zimowoja Teja. Jest to w znaczącej mierze powielenie wcześniejszych zapisów znajdujących się na kartach 164-181. Wielokrotnie zaburzony jest także porządek chronologiczny wydarzeń. Omawiając kwestię działalności w Radzie Narodowej RP na uchodźstwie, niespodziewanie na dwóch kartach pojawiają się okoliczności rozłamu, jaki nastąpił w emigracyjnym PSL w 1954 r.

Być może prace nad wspomnieniami przyczyniły się do podjęcia przez Zarembę ostatecznej decyzji o powrocie do Polski. Przebywając na emigracji, boleśnie odczuwał rozłąkę z krajem. We wspomnianym już liście z 12 lutego 1966 r. zapisał: „Myślę nieraz, czy by nie lepiej było wrócić do Polski [...] Chciałoby się złożyć swoje kości w tej ziemi, która dała mi pierwszy kawałek chleba. Chciało [by] się jeszcze spotkać z dawnych już czasów z kolegami ludowcami" 28 . Słowa te są dowodem tęsknoty autora za ojczyzną. Pragnie on wrócić do kraju dzieciństwa i wspomnień z nim związanych. Tak w analizowanym dziele, jak i korespondencji z działaczami ludowymi w kraju dawał do zrozumienia, iż jest rozczarowany postawą działaczy emigracyjnych, rozgrywkami personalnymi. Przede wszystkim jednak, że na emigracji czuł się obco, nie mogąc się realizować w roli społecznika, działacza chłopskiego, trybuna ludowego.

\section{Konwencja stylistyczna}

Moje wspomnienia Władysława Zaremby nie dają się ująć w ramy konkretnej konwencji stylistycznej. Narracja jest w znacznej mierze typowa dla wspomnień, po części dla pamiętników, a także diariuszy za sprawą wtopionych w tekst różnorodnych notatek, dokumentów, np. pismo 
kierownika Referatu Osiedleńczego Starostwa Powiatowego w Głubczycach z dn. 26 lipca 1948 r. nakazujące Zarembie osiedlenie się poza terenem powiatu lub protokół z posiedzenia NKW PSL w Nowym Jorku z dn. 21 września 1954 r.

Styl miejscami przypomina zapis relacji ustnej, ze względu na brak zachowania jakichkolwiek form pisarskich. Język wypowiedzi, używanie miejscami przez autora wyrażeń typowych dla gwary ludności kresowej (np. perekińczyk - zdrajca) oraz różnorodność podejmowanych zdarzeń o znacznym marginesie historycznym, zbliżony jest do gawędy o przeszłości. Miejscami tok narracji ma znamiona autobiografii, sprawozdania autora ze swej działalności publicznej. Motywy autobiograficzne są szczególnie zauważalne przy opisie dzieciństwa i okresu wczesnej młodości, a także zsyłki syberyjskiej. Niekiedy tok narracji staje się udramatyzowanym wykładem o dziejach naszego kraju, o kulturze chłopów kresowych, przede wszystkim jednak jest krytyczną relacją działacza ludowego o rządach sanacyjnych i komunistycznych w Polsce.

Wspomnienia Zaremby są źródłem nieadresowanym. Jednakże dzięki swej wymowie semantycznej wydają się przydatne dla szerokiego kręgu humanistów: przede wszystkim historyków, a także politologów, filologów, etnografów.

Nie bez znaczenia przy dalszej analizie tego dzieła winien być cały zespół zjawisk związanych z warsztatem pisarskim Zaremby. Ten ludowiec-samouk, przebywając w USA, bardzo często pisywał artykuły do czasopism emigracyjnych, wykazując się znaczną poprawnością stylu. Z zachowanej korespondencji wiadomo, że czytał pamiętniki Witosa, Rataja, Stapińskiego i wielu innych działaczy ludowych. Jednak stosowane przez nich style wypowiedzi nie znalazły odzwierciedlenia w tekście Władysława Zaremby. Należałoby również zwrócić uwagę na cechy, które determinowały ów warsztat autora: przede wszystkim jego wykształcenie, stan emocjonalny w momencie tworzenia poszczególnych partii tekstu, przynależność klasową i polityczną. Zespół tych cech miał olbrzymie znaczenie w konstrukcji omawianych wspomnień.

\section{Charakterystyka źródła}

Moje wspomnienia Władysława Zaremby nie są li tylko zapisem jego działalności politycznej bądź opowieścią autobiograficzną. W toku narracji autor przywołuje też opowieści przekazane mu przez innych, m.in. najstarszych mieszkańców rodzinnej wsi o sytuacji chłopstwa 
galicyjskiego w okresie pańszczyźnianym oraz rabacji Jakuba Szeli. W związku z tym zakres chronologiczny wydarzeń opisywanych we wspomnieniach sięga od połowy XIX do połowy wieku XX.

Zakres terytorialny jest również szeroki, obejmując Galicję i Podole, następnie Syberię, Anglię, Śląsk i Amerykę Północną. Los rzucał bowiem Władysława Zarembę po różnych zakątkach globu.

Autor dba o rzeczowość, dokumentarność, jednocześnie konotując bogactwo osób i informacji. Należy jednak zwrócić uwagę na fakt, iż jest to źródło nie tylko do dziejów wsi galicyjskiej, ruchu ludowego i historii politycznej naszego kraju. Przede wszystkim jest to źródło niezbędne do poznania osoby samego Zaremby, działacza ludowego, społecznika, polityka.

Zagłębiając się w treść wspomnień, należy stwierdzić, iż są one niejednorodne. Uwypuklona zostaje przede wszystkim działalność społeczna i polityczna Zaremby w okresie międzywojennym. W miarę obejmowania przez niego coraz wyższych stanowisk w ruchu ludowym rozszerza się horyzont wydarzeń ukazywanych czytelnikowi. Sposób ujęcia tematu jest taki, że w ostatecznym rezultacie jego wspomnienia wywołują wrażenie opowiadania bardzo bezpośredniego i szczerego, osobistych doświadczeń i przeżyć autora. Jednakże ze względu na fakt, iż pisane są a priori, należy przypuszczać, że przyczyny, jak również skutki wielu decyzji podejmowanych przez niego w przeszłości - wówczas w obliczu wielu niewiadomych - po latach interpretował w zupełnie innym świetle, z korzyścią dla siebie.

Perspektywa opisywanych wydarzeń ulega gwałtownemu skurczeniu z chwilą udziału w tzw. wielkiej polityce polskiego ruchu ludowego - na obczyźnie (w Radzie Narodowej) a także w kraju (w Krajowej Radzie Narodowej oraz centralnych strukturach PSL).

Całość wspomnień można podzielić, zaznaczając od razu, iż sztucznie - bowiem Zaremba sam nie podzielił swego dzieła - na kilka części. Pierwsza - dość spójna pod względem chronologicznym - to zarys jego dzieciństwa i młodości. Autor wprowadza czytelnika w klimat życia chłopów galicyjskich przełomu wieków. Kreśli obraz obyczajów chłopskich, ich zmagania się z codziennymi trudnościami, m.in. ubóstwem (opis nędznych posiłków spożywanych w domu rodzinnym Zaremby) i chorobami (wysoka śmiertelność z powodu gruźlicy), barierami społecznymi i cywilizacyjnymi (np. ojciec Zaremby, który bał się podróżować koleją). 
Kolejna część, najobszerniejsza, to przede wszystkim obraz Zaremby jako działacza ludowego i społecznika doby międzywojennej. Druga Rzeczpospolita mogła być dla ruchu ludowego okresem wspaniałego rozwoju. Po latach prześladowań i różnego rodzaju nacisków chłopi zyskali wreszcie prawo do politycznego samostanowienia. Tymczasem nie był to okres świetności dla ludowców. Zaremba pomija milczeniem przyczyny hamujące rozwój ruchu ludowego w pierwszych latach niepodległości Polski. Nie wspomina o tarciach i podziałach w łonie ludowców, wszelkie niepowodzenia zrzucając na Piłsudskiego i jego żądzę władzy. Swą uwagę przede wszystkim skupia na rządach sanacyjnych, tak jakby po wojnie polsko-bolszewickiej natychmiast nastąpił przewrót majowy. Po części może to wynikać z własnych doświadczeń autora oraz jego horyzontu lokalnego, z poziomu którego wielu rzeczy mógł jeszcze nie dostrzegać. Należy jednak wątpić, by bieżące wydarzenia polityczne i rozłamy w ruchu ludowym nie były komentowane w lokalnym środowisku ludowym. Wiadomo, iż Zaremba aktywnie uczestniczył w rozwoju ruchu ludowego na terenie powiatu podhajeckiego, województwa tarnopolskiego i lwowskiego. Na kartach swych wspomnień wszak wielokrotnie odwołuje się do przeróżnych zjazdów członków Stronnictwa Ludowego zarówno szczebla powiatowego, jak i wojewódzkiego.

Wiele miejsca poświęca także omówieniu problematyki wielkiego strajku chłopskiego w 1937 r. W sposób niezwykle precyzyjny przedstawia jego genezę i przebieg na terenie powiatu. Obszernie relacjonuje też kwestie represji policyjnych zastosowanych wobec uczestników strajku, przede wszystkim swoje doświadczenia z ówczesnym wymiarem sprawiedliwości.

Nie należąc do środowiska legionowego, a nawet otwarcie występując przeciwko niemu, nie schlebiając decydentom i urzędnikom, skrupulatnie odnotowywał swój awans „na szczyty społeczne”. Przypomnijmy, że został radnym gminy, następnie na prośbę starosty powiatowego wójtem gminy Halicz. Zaangażował się również w rozwój spółdzielczości ${ }^{29}$, kierując kilkoma spółdzielniami - także z inspiracji miejscowych władz powiatowych. Kolejne stanowiska, które były mu przydzielane przez przedstawicieli ówczesnych władz samorządowych,

29 H. Trocka, Spółdzielczość w programach i polityce polskich stronnictw ludowych do roku 1939, Warszawa 1969, s. 196. 
uważał za urzędową chęć ograniczenia jego działalności politycznej w ruchu ludowym. Nigdy jednak, co trzeba podkreślić, nie zabiegał o te stanowiska. Wszystkie, które osiągnął, traktował jako dowód uznania jego pracy koncepcyjnej i organizacyjnej.

Innym wybijającym się motywem opisywanym przez Zarembę są stosunki polsko-ukraińskie. Podkreśla on przyjazny stosunek ludności ukraińskiej do osadników polskich przez cały okres jego pobytu na Kresach.

Do części trzeciej należałoby zaliczyć doświadczenia wojny i okupacji sowieckiej oraz zsyłki na Syberię i do Uzbekistanu. Jak wspominał, szykany władz oraz NKWD wobec Polaków były na porządku dziennym. W sposób niezwykle sugestywny Zaremba nakreślił tu dramat ludzi wyrwanych z własnego mikrokosmosu, zdanych na łaskę i niełaskę władz sowieckich. Trudne warunki generowały różne postawy i zachowania ludzi. Gdy wielu ludzi popadło w apatię, rozwijała się atmosfera ogólnego zniechęcenia, Zaremba kupił w Taszkiencie jałówkę oraz kawałek pola, który uprawiał celem utrzymania rodziny. Jak z żalem wspominał po latach, był za swą przedsiębiorczość szykanowany przez innych Polaków.

Obraz Zaremby jako polityka, jednego z bliskich współpracowników Stanisława Mikołajczyka zarówno na uchodźstwie, jak i w kraju - można zaliczyć do części czwartej. Autor skrupulatnie odnotowuje swój awans, jednakże mało informuje o kulisach wielkiej polityki, w której uczestniczył ${ }^{30}$. Zamiast tego obszernie opisuje rozłamy i tarcia w rządzie polskim na uchodźstwie oraz tamtejszym ruchu ludowym. Podobnie sytuacja przedstawia się w kwestii udziału Zaremby w pracach KRN a także działalności we władzach naczelnych PSL w kraju. Z tekstu wspomnień wyłania się obraz działacza ludowego skupionego wyłącznie na rozwoju otrzymanego gospodarstwa rolnego w Boguchwałowie, który prześladowany jest przez władze administracyjnopolicyjne państwa niemal wyłącznie za przekonania polityczne.

Wiadomo, iż Zaremba brał udział w Kongresie PSL w styczniu 1946 r. Wszedł w skład Prezydium Kongresu, został przewodniczącym podkomisji Ziem Odzyskanych, opracowując postulaty dotyczące tego

30 Por. w tym zakresie Polski ruch ludowy na emigracji. Tom 1: (1944-1954), dokumenty i materiały wydał R. Turkowski, Kielce 2005, s. 90 nn. 
obszaru, wybrano go do Rady Naczelnej PSL ${ }^{31}$. Współtworzył struktury PSL na terenie województwa śląsko-dąbrowskiego, aktywnie uczestniczył w kampanii wyborczej do Sejmu Ustawodawczego na przełomie 1946 i 1947 r. Jednakże większość z tych zagadnień albo w ogóle, albo w stopniu minimalnym została poruszona przez Zarembę. Szczegółowo natomiast opisuje sankcje aparatu bezpieczeństwa wymierzone w jego osobę. Fragmenty poświęcone aresztowaniu, pobycie w więzieniach UB, prowadzonych wówczas przesłuchaniach w konfrontacji z zachowaną dokumentacją aparatu bezpieczeństwa wskazują na niezwykłą dbałość Zaremby o pełne odzwierciedlenie rzeczywistości w swoim opisie.

Dystans do polityki PSL, jaki zachowuje w końcowych fragmentach swych wspomnień Zaremba, mógł mieć związek z osobą Stanisława Mikołajczyka. To, co osiągnął Zaremba, zawdzięczał w dużej mierze właśnie prezesowi PSL. Jednakże osoba prezesa była przez Zarembę - w momencie powstawania wspomnień - postrzegana w sposób pejoratywny. Skupienie się na osobistych przeżyciach oraz kwestii pracy na roli uwalniało Zarembę od konieczności opisu meandrów polityki Polskiego Stronnictwa Ludowego, a tym samym osoby jego prezesa.

Władysław Zaremba żył w czasach nader intensywnych przemian świadomościowych, kulturowych, gospodarczych, zwłaszcza w środowisku wiejskim. W tej sytuacji Moje wspomnienia mogą być dla historyka nieocenioną pomocą do zrozumienia postrzegania ówczesnych wydarzeń z perspektywy działacza chłopskiego. Stanowią one również cenne źródło przede wszystkim ze względu na osobę autora, jednego z ważniejszych działaczy polskiego ruchu ludowego XX w. Wydaje się, iż po udostępnieniu tekstu szerokiemu gronu odbiorców wspomnienia Władysława Zaremby wejdą na stałe do literatury pamiętnikarskiej, wzbogacając w niej nurt pamiętnikarstwa chłopskiego o pozycję pierwszorzędnej wartości.

31 Kongres Polskiego Stronnictwa Ludowego 19-21 styczeń 1946 r. (stenogram), wybór, wstęp i oprac. J. Gmitruk, J. Mazurek, Warszawa 1999, s. 13, 111, 151, 241. Postulaty dotyczące Ziem Odzyskanych - s. 152-156. 
Władysław Zaremba was one of the leaders of the Polish Peasants' Party in country and abroad, a member of the Polish governmentin-exile during WW2, and a deputy to State National Council. However, he is almost completely forgotten nowadays. Historians were not aware of the fact that, while he was an expatriate in USA in 1965-1966, Władysław Zaremba wrote down his memoirs. The typescript was commandeered from Zaremba by the SB (the secret police) when he came back to the country in 1967 and was never returned to him. Establishing the Institute of National Remembrance (Instytut Pamięci Narodowej) gave many researchers an access to the former SB files, among which were Wladysław Zaremba's accounts. The aim of the author of the article is to introduce the reader to information regarding Zaremba's political and social activity. The author also gives a brief characteristics of the memoirs, by specifying when and how they came into being, and discusses their content through the style of the testimony. An analysis of the typescript brings a conclusion, that it is the key to the history of the Galician countryside, peasants' movement and Poland's political history, but even more so - to understanding Władysław Zaremba - a peasant, social activist and politician - himself. 